\title{
Paracoccus sphaerophysae sp. nov., a siderophore-producing, endophytic bacterium isolated from root nodules of Sphaerophysa salsula
}

\author{
Correspondence \\ Ge-Hong Wei \\ weigehong@yahoo.com.cn
}

\author{
Zhen-Shan Deng, ${ }^{1,2}$ Long-Fei Zhao, ${ }^{1}$ Lin Xu, ${ }^{1}$ Zhao-Yu Kong, ${ }^{1}$ \\ Peng Zhao, ${ }^{1}$ Wei Qin, ${ }^{1}$ Jia-Li Chang ${ }^{1}$ and Ge-Hong Wei ${ }^{1}$ \\ ${ }^{1}$ College of Life Sciences, Shaanxi Key Laboratory of Molecular Biology for Agriculture, Northwest \\ A \& F University, Yangling, Shaanxi 712100, PR China \\ ${ }^{2}$ College of Life Sciences, Yan-an University, Yan-an, Shaanxi 716000, PR China
}

\begin{abstract}
An aerobic, brown-pigmented, non-spore-forming, endophytic bacterium, designated strain $\mathrm{Zy}-3^{\top}$, was isolated from root nodules of Sphaerophysa salsula, a native leguminous herb belonging to the family Leguminosae growing in north-western China. Cells of strain $Z y-3^{\top}$ were non-motile, Gram-negative rods. Strain $Z y-3^{\top}$ produced siderophores and showed antifungal activity. Phylogenetic analysis of the 16S rRNA gene sequence indicated that the closest relative of this organism was Paracoccus halophilus $\mathrm{HN}-182^{\top}$ ( $96.6 \%$ sequence similarity). On the basis of genotype, fatty acid patterns and physiological characteristics, a novel species Paracoccus sphaerophysae sp. nov. is proposed, with $\mathrm{Zy}-3^{\top}\left(=\mathrm{ACCC} 05413^{\top}=\mathrm{HAMBI} 3106^{\top}\right)$ as the type strain.
\end{abstract}

As an essential element for micro-organisms (Loper \& Buyer, 1991), iron also plays an important part in some host-bacteria interactions (Mila et al., 1996). Under ironlimited conditions, micro-organisms produce siderophores (low-molecular-mass biomolecules, $0.5-1.5 \mathrm{kDa}$ ) in order to scavenge ferric ions, which bind with high affinity to specific outer-membrane receptors. The major groups of siderophores for the chelation of $\mathrm{Fe}^{3+}$ include hydroxamates, thiohydroxamates and catecholates (Richardson et al., 1999). Because of their role in biological control of plant diseases, the production of siderophores by plantassociated bacteria has received major attention (Loper \& Buyer, 1991).

The genus Paracoccus was first described by Davis et al. (1969), and the description was later emended by Katayama et al. (1995). It consists of Gram-negative, oxidase- and catalase-positive bacteria that show substantial metabolic versatility. Phylogenetically, the genus belongs to the $\alpha-3$ subgroup of the Proteobacteria. In this study, an endophytic, brown-pigmented, siderophoreproducing bacterial strain, $\mathrm{Zy}-3^{\mathrm{T}}$, was isolated from root nodules of Sphaerophysa salsula, a native leguminous herb belonging to the family Leguminosae growing in northwestern China. Based on phenotypic and genotypic studies,

The GenBank/EMBL/DDBJ accession number for the 16S rRNA gene sequence of strain Zy-3' is GU129567.

Two supplementary figures are available with the online version of this paper. it is concluded that this endophytic isolate represents a novel species within the genus Paracoccus.

The GPS coordinates for the sampling site from which strain $\mathrm{Zy}-3^{\mathrm{T}}$ was obtained were $38^{\circ} 45^{\prime} 07^{\prime \prime} \mathrm{N} 100^{\circ} 22^{\prime} 10^{\prime \prime}$ E. Healthy, non-ruptured nodules were carefully rinsed with sterile distilled water to remove soil, placed in a finemesh plastic holder and surface-sterilized by immersion in $95 \%$ ethanol for $30 \mathrm{~s}$ and then in $5 \%$ sodium hypochlorite for $3 \mathrm{~min}$ and finally rinsed eight times with sterile distilled water. The surface-sterilized root nodules were crushed on a sterile plate and bacteria were isolated on nutrient agar (NA) containing (per litre distilled water) $5.0 \mathrm{~g} \mathrm{NaCl}, 5.0 \mathrm{~g}$ peptone, $1.5 \mathrm{~g}$ yeast extract, $1.5 \mathrm{~g}$ beef extract and $20 \mathrm{~g}$ agar, $\mathrm{pH}$ 7.2. Isolates were incubated at $28{ }^{\circ} \mathrm{C}$, and the purity of the colonies was checked by repeated streaking of single colonies on plates and by microscopic examination. Pure cultures were preserved at $4{ }^{\circ} \mathrm{C}$ for temporary storage or in $20 \%$ glycerol at $-80{ }^{\circ} \mathrm{C}$ for long-term storage. Surface-sterilized nodules were rolled on NA plates and aliquots of the sterile distilled water from the final rinse solution were plated onto NA plates as controls to detect possible contaminants.

The Chromeazurol S (CAS) assay (Schwyn \& Neilands, 1987) was used to detect siderophores. Routine cultivation was conducted at $28{ }^{\circ} \mathrm{C}$ on NA. The Gram reaction was determined by staining cells grown on NA at $28{ }^{\circ} \mathrm{C}$ for $24 \mathrm{~h}$, according to the method described by Gerhardt et al. (1994). Endospore formation was detected by malachite green staining. Cultured cells were adsorbed onto a sterile 
filter after reaching the exponential growth phase and then fixed with $3 \%$ glutaraldehyde in cacodylate buffer $(0.1 \mathrm{M}$, $\mathrm{pH}$ 7.2) for $1 \mathrm{~h}$ at room temperature (Robinson et al., 1984). The samples were washed, dehydrated with a graded ethanol series, critical-point-dried and sputter-coated with a gold film; samples were then examined in a JEOL JSM6360 digital scanning electron microscope (Fig. 1).

Strain $\mathrm{Zy}-3^{\mathrm{T}}$ and reference strain Paracoccus halophilus CGMCC $1.6117^{\mathrm{T}}$ (Liu et al., 2008) were grown on NA, and subjected to physiological and biochemical tests, including indole production from tryptophan, phosphate solubilization activity and chitinase activity according to Dong \& Cai (2001). To test for antifungal activity, spores of fungal cultures (Fusarium oxysporium, Alternaria burnsii and Rhizoctonia solani) were grown on potato dextrose agar (PDA) plates. An agar plug (5 mm diameter) taken from an actively growing fungal culture was placed to one side on the surface of a PDA plate. Test bacteria were streaked perpendicular to the agar plug on the opposite side, towards the edge of the plate. Plates inoculated with fungal agar plugs alone were used as controls. Plates were incubated at $28 \pm 2{ }^{\circ} \mathrm{C}$ until fungal mycelium covered the agar surface completely in the control plate, and zones of inhibition were recorded. A test was considered positive when bacteria interfered with the normal spread of the fungus and presented an inhibition zone in three replications. Sensitivity to antibiotics was examined by spreading cells (0.5 McFarland) onto NA and placing discs (Difco) on the plates containing the following antibiotics: ampicillin $(100 \mu \mathrm{g})$, chloramphenicol $(50 \mu \mathrm{g})$, kanamycin $(50 \mu \mathrm{g})$, penicillin $\mathrm{G}(10 \mathrm{U})$ and streptomycin $(50 \mu \mathrm{g})$. The diameters of inhibition zones were measured after $48 \mathrm{~h}$ of incubation at $28{ }^{\circ} \mathrm{C}$.

To determine the optimal growth temperature of the test strain, cultures were incubated between 4 and $70{ }^{\circ} \mathrm{C}$ on NA plates for 7 days. The influence of $\mathrm{pH}$ on growth was determined between $\mathrm{pH} 3.0$ and 11.5 by using appropriate

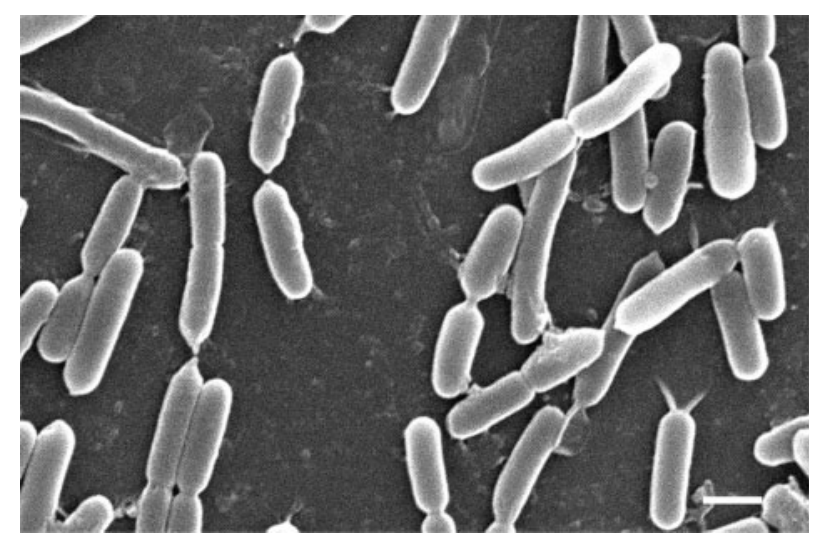

Fig. 1. Scanning electron micrograph of exponential-phase cells, showing the cell morphology of strain $Z y-3^{\top}$. Original magnification $\times 10000$. Bar, $1 \mu \mathrm{m}$. biological buffers (Chung et al., 1995), and growth was monitored by the $\mathrm{OD}_{595}$ of the culture in nutrient broth (NB; as NA without agar) at $28{ }^{\circ} \mathrm{C}$ for 7 days on a shaker. $\mathrm{NaCl}$ tolerance was measured in $\mathrm{NB}$ at $1-9 \%(\mathrm{w} / \mathrm{v}) \mathrm{NaCl}$, with shaking at $28{ }^{\circ} \mathrm{C}$ for 7 days. Motility was determined with an optical microscope using the hanging-drop technique (Skerman, 1967). Acid production from some carbohydrates was detected using the method of Hugh \& Leifson (1953). Filter-sterilized carbohydrate solutions were added at $1 \%(\mathrm{w} / \mathrm{v})$, and acid production was recorded after 7 and 14 days of incubation. To test for growth on reduced sulfur and elemental sulfur, the test strain was cultivated for 14 days in Allen's medium (Allen, 1959), which was modified by the addition of elemental sulfur, sulfide, thiosulfate or sulfite (each at $1 \%$ ) as energy sources, and the $\mathrm{pH}$ was adjusted to 6.5. Growth was monitored by measuring turbidity at $600 \mathrm{~nm}$ after 10 days of incubation at $28{ }^{\circ} \mathrm{C}$ with shaking. Starch hydrolysis was determined as described by Cowan \& Steel (1965). Denitrification was determined by growth and gas formation in a stab culture of NA containing $0.1 \%(\mathrm{w} / \mathrm{v})$ agar. Catalase activity was determined by the formation of bubbles in a $3 \% \mathrm{H}_{2} \mathrm{O}_{2}$ solution. Oxidase activity was determined by oxidation of $1 \% p$-aminodimethylaniline oxalate. Urease production was determined as described by Lányí (1987). Strain $\mathrm{Zy}-3^{\mathrm{T}}$ and P. halophilus CGMCC $1.6117^{\mathrm{T}}$ were cultivated for 3 days at $28{ }^{\circ} \mathrm{C}$ on trypticase soy agar (TSA) adjusted to $\mathrm{pH}$ 8.0. Harvesting, saponification, methylation and extraction of fatty acid methyl esters were performed according to Sasser (1990). Fatty acid methyl esters were identified by GC-MS, as described previously (Lipski \& Altendorf, 1997). Quinones were determined as described by Collins (1985) and $\mathrm{Wu}$ et al. (1989). The brown coloration of the bacterium was due to the biosynthesis of carotenoids within the cells. Pigments were extracted from the cells with acetone, and reversedphase HPLC of the extracted pigment was carried out by using procedures described previously (Fraser et al., 1997) with minor modifications. Carotenoids present in the sample were identified by comparing retention times with an individual reference standard (Sigma).

The DNA base compositions of strain $\mathrm{Zy}-3^{\mathrm{T}}$ and $P$. halophilus CGMCC $1.6117^{\mathrm{T}}$ were determined by thermal denaturation (Marmur \& Doty, 1962) using $0.1 \times$ SSC $(1 \times$ SSC is $0.15 \mathrm{M} \mathrm{NaCl}$ plus $0.015 \mathrm{M}$ sodium citrate). The midpoint of thermal denaturation of DNA $\left(T_{\mathrm{m}}\right)$ was determined graphically after correction of absorbance values for thermal solvent expansion. The $\mathrm{G}+\mathrm{C}$ content $(\mathrm{mol} \%)$ was calculated from the following equation: $\mathrm{G}+\mathrm{C}=2.08 T_{\mathrm{m}}-106.4$, based on thermal denaturation in $0.1 \times$ SSC (Owen et al., 1969). Total DNA was extracted according to the method of Terefework et al. (2001) and used as a template to amplify the 16S rRNA gene with primers $\mathrm{fD} 1$ and $\mathrm{rD1}$ (Weisburg et al., 1991). Procedures described by Van Berkum et al. (1996) were used for PCR amplification of the full-length 16S rRNA gene. 16S rRNA gene sequences were aligned using the programs in 
CLUSTAL_X version 1.83 (Thompson et al., 1994, 1997). Phylogenetic trees were reconstructed with sequence alignments of $1360 \mathrm{nt}$ by the neighbour-joining method and the Jukes-Cantor model and bootstrapped with 1000 replications using TREECON version 1.3b (Van de Peer \& De Wachter, 1994), by maximum-likelihood analysis using the PHYLIP package (Felsenstein, 1989) and by maximumparsimony analysis using MEGA version 4.0 (Tamura et al., 2007) with 1000 bootstrap replications.

Compared with other Paracoccus species, strain $\mathrm{Zy}-3^{\mathrm{T}}$ was characterized by growth at 4 and $60{ }^{\circ} \mathrm{C}$. The optimal growth temperature was $28{ }^{\circ} \mathrm{C}$. Growth was observed in 1$6 \% \mathrm{NaCl}$, the optimum being $3 \%$; when the $\mathrm{NaCl}$ concentration in the medium was increased to $7 \%$, growth was slow, and no growth occurred in the presence of more than $8 \% \mathrm{NaCl}$. Strain $\mathrm{Zy}-3^{\mathrm{T}}$ was able to grow at $\mathrm{pH} 5-11$, with optimum growth at $\mathrm{pH}$ 7.5. Further physiological and biochemical properties of strain $\mathrm{Zy}-3^{\mathrm{T}}$ are provided in the species description and a comparison of strain $Z y-3^{T}$ with

Table 1. Differential properties of strain $\mathrm{Zy}-3^{\top}$ and $P$. halophilus CGMCC $1.6117^{\top}$

All data are from this study. Both strains are non-motile, do not grow at $\mathrm{pH} 4.5$ or reduce nitrate to nitrogen, are negative for utilization of sucrose, ethanol, Tweens and starch and for utilization of sulfide and thiosulfate as energy sources and are resistant to ampicillin and penicillin G. Both strains are positive for urease activity and utilization of L-arabinose, D-galactose, D-mannose, D-fructose and $\mathrm{D}$-xylose and are sensitive to kanamycin and streptomycin.

\begin{tabular}{|c|c|c|}
\hline Characteristic & $Z y-3^{T}$ & $\begin{array}{c}\text { P. halophilus } \\
\text { CGMCC } 1.6117^{\mathrm{T}}\end{array}$ \\
\hline Pigmentation & + & - \\
\hline \multicolumn{3}{|l|}{ Utilization of: } \\
\hline Maltose & + & - \\
\hline Lactose & + & - \\
\hline Inositol & + & - \\
\hline Sodium hippurate & + & - \\
\hline$\alpha$-Naphthylacetic acid & + & - \\
\hline Chitosan & - & + \\
\hline Antifungal activity & + & - \\
\hline Phosphate solubilization activity & - & + \\
\hline Sensitivity to chloramphenicol ${ }^{\star}$ & - & + \\
\hline Methyl red test & - & + \\
\hline Voges-Proskauer test & - & + \\
\hline \multicolumn{3}{|l|}{ Growth at/in: } \\
\hline $4{ }^{\circ} \mathrm{C}$ & + & - \\
\hline $60{ }^{\circ} \mathrm{C}$ & + & - \\
\hline pH 10.0 & + & - \\
\hline $8 \% \mathrm{NaCl}$ & - & + \\
\hline DNA G $+C$ content $(\mathrm{mol} \%)$ & 67.1 & 67.2 \\
\hline
\end{tabular}

${ }^{*}$ Zones of inhibition were measured from the edge of the disc to the edge of the clear zone. -, Resistance (inhibition zone $<2 \mathrm{~mm}$ ); + , sensitivity (inhibition zone $\geqslant 2 \mathrm{~mm}$ ).
P. halophilus CGMCC $1.6117^{\mathrm{T}}$ is given in Table 1. Strain $\mathrm{Zy}-3^{\mathrm{T}}$ was capable of aerobic growth on CAS agar plates, and haloes formed around colonies, revealing that it produced siderophores. The antifungal activity of strain $\mathrm{Zy}-3^{\mathrm{T}}$ was checked and the strain exhibited broadspectrum activity against test fungi, with inhibition zones $18.2-23.7 \mathrm{~mm}$ in diameter. Strain $\mathrm{Zy}-3^{\mathrm{T}}$ was resistant to ampicillin, chloramphenicol and penicillin $\mathrm{G}$ and sensitive to kanamycin and streptomycin.

Strain $\mathrm{Zy}-3^{\mathrm{T}}$ contains ubiquinone 10 as the sole quinone. The fatty acid profile $\left(\mathrm{C}_{18: 1} \omega 7 c, 74.98 \%\right.$; $\mathrm{C}_{18: 0}, 5.15 \%$; $\mathrm{C}_{10: 0} 3-\mathrm{OH}, 1.47 \%$; anteiso- $\mathrm{C}_{15: 0}, 6.10 \%$; $\mathrm{C}_{14: 0} 3-\mathrm{OH}$, $\left.0.44 \% ; \mathrm{C}_{17: 0}, 1.11 \% ; \mathrm{C}_{16: 0}, 3.04 \%\right)$ was characteristic of alphaproteobacteria. The major cellular fatty acid was $\mathrm{C}_{18: 1} \omega 7 c$, and the major hydroxy fatty acid was $\mathrm{C}_{10: 0} 3-$ $\mathrm{OH}$. The fatty acid profiles of strain $\mathrm{Zy}-3^{\mathrm{T}}$ and $P$. halophilus CGMCC $1.6117^{\mathrm{T}}$ are compared in Table 2 . Carotenoid production was confirmed by HPLC analysis. One of the major carotenoids produced by strain $\mathrm{Zy}-3^{\mathrm{T}}$ was $\beta$-carotene, which was identified by the retention time of the peak being almost identical to that of standard $\beta$ carotene (19.899 vs 19.988 min; see Supplementary Fig. S1, available in IJSEM Online). The DNA G $+\mathrm{C}$ content of strain $\mathrm{Zy}-3^{\mathrm{T}}$ was $67.1 \mathrm{~mol} \%$. 16S rRNA gene sequence analysis indicated that strain $\mathrm{Zy}-3^{\mathrm{T}}$ was related to $P$. halophilus $\mathrm{HN}-182^{\mathrm{T}}$ with the highest similarity, 96.6\%. Other closely related species included Paracoccus solventivorans $(96.1 \%$ similarity to the type strain), $P$. versutus (96.0\%) and P. pantotrophus (95.3\%). Phylogenetic trees were constructed with the neighbour-joining (Fig. 2), maximum-parsimony (Supplementary Fig. S2a) and maximum-likelihood (Supplementary Fig. S2b) methods. These methods generated slightly different tree topologies, but strain $\mathrm{Zy}-3^{\mathrm{T}}$ and $P$. halophilus $\mathrm{HN}-182^{\mathrm{T}}$ generated a coherent cluster in all three trees.

Table 2. Fatty acid compositions of strain $Z y-3^{\top}$ and $P$. halophilus CGMCC $1.6117^{\top}$

Values are percentages of total fatty acids and were obtained in this study. ND, Not detected.

\begin{tabular}{|lcc|}
\hline Fatty acid & Zy-3 $^{\mathbf{T}}$ & $\begin{array}{c}\text { P. halophilus CGMCC } \\
\mathbf{1 . 6 1 1 7}^{\mathbf{T}}\end{array}$ \\
\hline $\mathrm{C}_{10: 0} 3-\mathrm{OH}$ & 1.47 & 1.65 \\
$\mathrm{C}_{14: 0}$ & $\mathrm{ND}$ & 1.72 \\
$\mathrm{C}_{14: 0} 3-\mathrm{OH}$ & 0.44 & 0.92 \\
iso- $_{15: 0}$ & 1.27 & 0.35 \\
anteiso-C $_{15: 0}$ & 6.10 & 0.42 \\
iso- $_{15: 1} \mathrm{I}$ & $\mathrm{ND}$ & 0.93 \\
$\mathrm{C}_{16: 0}$ & 3.04 & 10.03 \\
$\mathrm{C}_{17: 0}$ & 1.11 & 3.11 \\
anteiso-C $_{17: 0}$ & 3.52 & 0.55 \\
$\mathrm{C}_{17: 1} \omega 8 c$ & 0.84 & 1.17 \\
$\mathrm{C}_{18: 0}$ & 5.15 & 9.10 \\
$\mathrm{C}_{18: 1} \omega 7 c$ & 74.98 & 63.28 \\
\hline
\end{tabular}




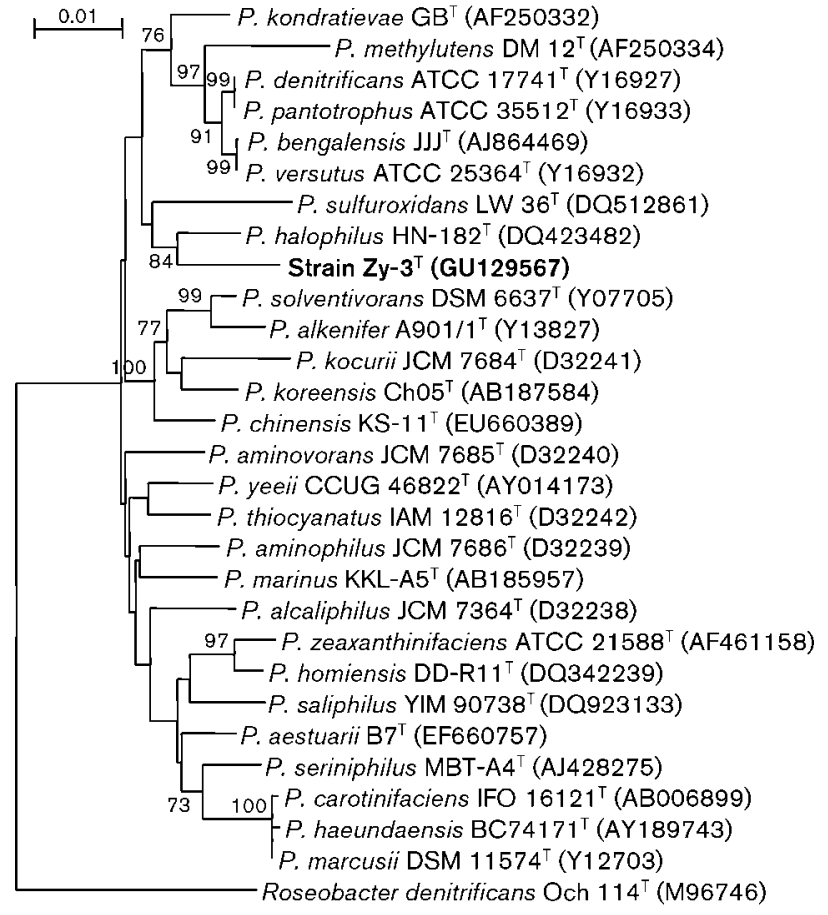

Fig. 2. Phylogenetic tree constructed with the neighbour-joining method based on 16S rRNA gene sequence evolutionary distances among strain $\mathrm{Zy}-3^{\top}$ and other members of the genus Paracoccus. Bootstrap values (expressed as percentages of 1000 replications) greater than $70 \%$ are shown at branching points. The sequence of Roseobacter denitrificans Och $114^{\top}$ was used as an outgroup. Bar, $1 \%$ nucleotide substitution. Maximum-parsimony and maximumlikelihood trees are available in Supplementary Fig. S2.

Combining the phenotypic and genotypic differences stated above, it is concluded that strain $\mathrm{Zy}-3^{\mathrm{T}}$ represents a novel species of the genus Paracoccus, for which the name Paracoccus sphaerophysae sp. nov. is proposed.

\section{Description of Paracoccus sphaerophysae sp. nov.}

Paracoccus sphaerophysae (sphae.ro.phy'sae. N.L. gen. n. sphaerophysae of Sphaerophysa, a genus of leguminous plants, referring to the origin of the type strain).

Cells are Gram-negative, non-motile, aerobic, non-sporeforming rods and grow as single cells $(0.4-0.8 \times 1.1-2.7 \mu \mathrm{m})$ or as pairs to short chains. Colonies on NA are circular, smooth, convex, non-glossy and cream-white to brown. Growth occurs at $4-60{ }^{\circ} \mathrm{C}$ (optimum $28{ }^{\circ} \mathrm{C}$ ), $1-6 \% \mathrm{NaCl}$ (optimum $3 \%$ ) and $\mathrm{pH}$ 5-11 (optimum pH 7.5). Capable of producing siderophores and showing antifungal activity. Positive for catalase, oxidase and urease activities. Negative for L-phenylalanine dehydrogenase, chitinase and phosphate solubilization activities. The methyl red and VogesProskauer tests are negative. Resistant to ampicillin, chloramphenicol and penicillin $\mathrm{G}$ and sensitive to kanamy- cin and streptomycin. No indole is produced from tryptophan. Agar, casein, starch, peptone broth, Tweens and gelatin are not hydrolysed. Utilizes L-cystine, L-cysteine, L-methionine, L-alanine, L-tryptophan, L-tyrosine, L-leucine, L-threonine, L-serine, L-histidine, L-arginine, L-glutamic acid, L-asparagine, L-aspartic acid, malonic acid, succinic acid, $\alpha$-naphthylacetic acid, hypoxanthine, L-arabinose, Dgalactose, maltose, D-mannose, D-fructose, lactose, inositol, D-xylose, D-ribose, raffinose, sodium hippurate, $(+)$ melibiose, L-rhamnose monohydrate, sodium pyruvate, Dsorbitol and glycerol. Does not utilize ethanol or sucrose. Nitrate is not reduced to nitrogen. Reduced sulfur does not support autotrophic growth. Glucose is not fermented. The sole ubiquinone is Q-10. The major cellular fatty acid ( $\sim 75 \%$ of the total fatty acids) is $\mathrm{C}_{18: 1} \omega 7 c$; minor fatty acids are $\mathrm{C}_{18: 0}, \mathrm{C}_{10: 0} 3-\mathrm{OH}$, anteiso- $\mathrm{C}_{15: 0}$, anteiso- $\mathrm{C}_{17: 0}, \mathrm{C}_{14: 0}$ $3-\mathrm{OH}, \mathrm{C}_{17: 0}, \mathrm{C}_{16: 0}$, iso- $\mathrm{C}_{15: 0}$ and $\mathrm{C}_{17: 1} \omega 8 \mathrm{c}$. Capable of producing $\beta$-carotene. The DNA G $+\mathrm{C}$ content of the type strain is $67.1 \mathrm{~mol} \%\left(T_{\mathrm{m}}\right)$.

The type strain, $\mathrm{Zy}-3^{\mathrm{T}}\left(=\mathrm{ACCC} 05413^{\mathrm{T}}=\mathrm{HAMBI} 3106^{\mathrm{T}}\right.$ ), was isolated from root nodules of Sphaerophysa salsula, a native legume growing in north-western China.

\section{Acknowledgements}

This work was supported by projects from the National Science Foundation of China $(30970003,30900215)$ and the National Basic Research Program of China (2010CB126502). We are grateful to Dr Kristina Lindström and Professor Jiang for deposition of the strain in their culture collections.

\section{References}

Allen, M. B. (1959). Studies with Cyanidium caldarium, an anomalously pigmented chlorophyte. Arch Mikrobiol 32, 270-277.

Chung, Y. C., Kobayashi, T., Kanai, H., Akiba, T. \& Kudo, T. (1995). Purification and properties of extracellular amylase from the hyperthermophilic archaeon Thermococcus profundus DT5432. Appl Environ Microbiol 61, 1502-1506.

Collins, M. D. (1985). Isoprenoid quinone analysis in classification and identification. In Chemical Methods in Bacterial Systematics, pp. 267-287. Edited by M. Goodfellow \& D. E. Minnikin. London: Academic Press.

Cowan, S. T. \& Steel, K. J. (1965). Manual for the Identification of Medical Bacteria. London: Cambridge University Press.

Davis, D. H., Doudoroff, M., Stanier, R. Y. \& Mandel, M. (1969). Proposal to reject the genus Hydrogenomonas: taxonomic implications. Int J Syst Bacteriol 19, 375-390.

Dong, X.-Z. \& Cai, M. -Y. (2001). Determinative Manual for Routine Bacteriology. Beijing: Scientific Press (English translation).

Felsenstein, J. (1989). PHYLIP - phylogeny inference package (version 3.2). Cladistics 5, 164-166.

Fraser, P. D., Miura, Y. \& Misawa, N. (1997). In vitro characterisation of astaxanthin biosynthetic enzymes. J Biol Chem 272, 61286135.

Gerhardt, P., Murray, R. G. E., Wood, W. A. \& Krieg, N. R. (editors) (1994). Methods for General and Molecular Bacteriology. Washington, DC: American Society for Microbiology. 
Hugh, R. \& Leifson, E. (1953). The taxonomic significance of fermentative versus oxidative metabolism of carbohydrates by various gram negative bacteria. J Bacteriol 66, 24-26.

Katayama, Y., Hiraishi, A. \& Kuraishi, H. (1995). Paracoccus thiocyanatus sp. nov., a new species of thiocyanate-utilizing facultative chemolithotroph, and transfer of Thiobacillus versutus to the genus Paracoccus as Paracoccus versutus comb. nov. with emendation of the genus. Microbiology 141, 1469-1477.

Lányí, B. (1987). Classical and rapid identification methods for medically important bacteria. Methods Microbiol 19, 1-67.

Lipski, A. \& Altendorf, K. (1997). Identification of heterotrophic bacteria isolated from ammonia-supplied experimental biofilters. Syst Appl Microbiol 20, 448-457.

Liu, Z.-P., Wang, B.-J., Liu, X.-Y., Dai, X., Liu, Y.-H. \& Liu, S.-J. (2008). Paracoccus halophilus sp. nov., isolated from marine sediment of the South China Sea, China, and emended description of genus Paracoccus Davis 1969. Int J Syst Evol Microbiol 58, 257-261.

Loper, J. E. \& Buyer, J. S. (1991). Siderophores in microbial interactions on plant surfaces. Mol Plant Microbe Interact 4, 5-13.

Marmur, J. \& Doty, P. (1962). Determination of the base composition of deoxyribonucleic acid from its thermal denaturation temperature. J Mol Biol 5, 109-118.

Mila, I., Scalbert, A. \& Expert, D. (1996). Iron withholding by plant polyphenols and resistance to pathogens and rots. Phytochemistry 42, 1551-1555.

Owen, R. J., Hill, L. R. \& Lapage, S. P. (1969). Determination of DNA base compositions from melting profiles in dilute buffers. Biopolymers 7, 503-516.

Richardson, N., Davies, J. A. \& Radüchel, B. (1999). Iron (III)-based contrast agents for magnetic resonance imaging. Polyhedron 18, $2457-$ 2482.

Robinson, R. W., Akin, D. E., Nordstedt, R. A., Thomas, M. V. \& Aldrich, H. C. (1984). Light and electron microscopic examinations of methane-producing biofilms from anaerobic fixed-bed reactors. Appl Environ Microbiol 48, 127-136.
Sasser, M. (1990). Identification of bacteria through fatty acid analysis. In Methods in Phytobacteriology, pp. 199-204. Edited by Z. Klement, K. Rudolph \& D. C. Sands. Budapest: Akademiai Kiado.

Schwyn, B. \& Neilands, J. B. (1987). Universal chemical assay for the detection and determination of siderophores. Anal Biochem 160, 47-56.

Skerman, V. B. D. (1967). A Guide to the Identification of the Genera of Bacteria, 2nd edn. Baltimore: Williams \& Wilkins.

Tamura, K., Dudley, J., Nei, M. \& Kumar, S. (2007). MEGA4: molecular evolutionary genetics analysis (MEGA) software version 4.0. Mol Biol Evol 24, 1596-1599.

Terefework, Z., Kaijalainen, S. \& Lindström, K. (2001). AFLP fingerprinting as a tool to study the genetic diversity of Rhizobium galegae isolated from Galega orientalis and Galega officinalis. J Biotechnol 91, 169-180.

Thompson, J. D., Higgins, D. G. \& Gibson, T. J. (1994). CLUSTAL W: improving the sensitivity of progressive multiple sequence alignment through sequence weighting, position-specific gap penalties and weight matrix choice. Nucleic Acids Res 22, 4673-4680.

Thompson, J. D., Gibson, T. J., Plewniak, F., Jeanmougin, F. \& Higgins, D. G. (1997). The CLUSTAL_X windows interface: flexible strategies for multiple sequence alignment aided by quality analysis tools. Nucleic Acids Res 25, 4876-4882.

Van Berkum, P., Beyene, D. \& Eardly, B. D. (1996). Phylogenetic relationships among Rhizobium species nodulating the common bean (Phaseolus vulgaris L.). Int J Syst Bacteriol 46, 240-244.

Van de Peer, Y. \& De Wachter, R. (1994). TREECON for Windows: a software package for the construction and drawing of evolutionary trees for the Microsoft Windows environment. Comput Appl Biosci 10, 569570 .

Weisburg, W. G., Barns, S. M., Pelletier, D. A. \& Lane, D. J. (1991). 16S ribosomal DNA amplification for phylogenetic study. J Bacteriol 173, 697-703.

Wu, C., Lu, X., Qin, M., Wang, Y. \& Ruan, J. (1989). Analysis of menaquinone compound in microbial cells by HPLC. Microbiology [English translation of Microbiology (Beijing)] 16, 176-178. 